\title{
One hundred years ago: the dawning of the insulin era
}

\author{
Massimo Porta ${ }^{1}$
}

Published online: 22 November 2020

(c) Springer-Verlag Italia S.r.l., part of Springer Nature 2020

\begin{abstract}
The dawn of the insulin era can be placed in 1921, when Banting and Best started their experiments which led, a year later, to the successful treatment of diabetes. They were preceded by the discoveries of the pancreatic cause of diabetes by Minkowski and von Mering in 1889 and of the islets by Paul Langerhans in 1869. The achievement of the first targeted treatment in medical history was a landmark of medical progress. However, it was accompanied by a mixture of human greatness and misery. Genius and recklessness, ambition and deception, camaraderie and rivalry, selflessness and pursuit of glory went along with superficial search of the existing literature, poor planning, faulty interpretation of results, failure to reproduce them, and misquoting of reports from other laboratories. Then as now, such faults surface whenever human nature aims to push forward the boundaries of knowledge and pose a real challenge in today's world, as the scientific method strives to keep healthy in the face of growing anti-scientific feelings.
\end{abstract}

Keywords Insulin $\cdot$ History of diabetes $\cdot$ History of medicine $\cdot$ Publication ethics

"The discovery of insulin at the University of Toronto in 1921-22 was one of the most dramatic events in the history of the treatment of disease. Insulin's impact was so sensational because of the incredible effect it had on diabetic patients. Those who watched the first starved, sometimes comatose, diabetics receive insulin and return to life saw one of the genuine miracles of modern medicine. They were present at the closest approach to the resurrection of the body that our secular society can achieve, and at the discovery of what has become the elixir of life for millions of human beings around the world."

Managed by Massimo Porta.

Massimo Porta

massimo.porta@unito.it

1 Department of Medical Sciences, University of Turin, Corso AM Dogliotti 14, 10126 Turin, Italy
No words are better to describe what happened a hundred years ago than the opening sentence of Michael Bliss's deeply researched book on "The Discovery of Insulin" [1] and how those events reverberate unabated to our days. Frederick Grant Banting had served as a surgeon in World War 1 in Europe. On October 20, 1920, after his return to Canada, he was reading a paper by Moses Barron describing a case of atrophy of the exocrine pancreas in a rare instance of duct obstruction caused by a stone [2], while preparing a lecture on carbohydrate metabolism. In his own later words "Finally, about two in the morning after the lecture and the article had been chasing each other through my mind for some time, the idea occurred to me that by the experimental ligation of the duct and the subsequent degeneration of a portion of the pancreas, one might obtain the internal secretion free from the external secretion" [3].

The way had been opened in 1889 by Oskar Minkowski and Josef von Mering, who demonstrated that removing the pancreas from a dog results in full-blown diabetes [4]. They suggested that the gland produces some substance that prevents diabetes and, if properly isolated, could cure it. There was no idea of what this substance could be. It took years before the suspect emerged that it might have something to do with the cell clusters described by a medical student, Paul Langerhans, in his 1869 doctoral thesis [5]. Minkowski himself started a sequence of experiments to produce extracts 
that could replace lost pancreatic function, but his and all subsequent attempts ended in failure, because ineffective, toxic or both.

Indeed, not all attempts had been fruitless. In Germany, Georg Ludwig Zuelzer had managed in 1906-7 to produce an extract that could briefly rescue eight patients from ketoacidotic coma [6]. Unfortunately, short supply of the extract (aptly named Acomatol), severe side effects, probably including then hardly known hypoglycaemia, and the outbreak of World War 1 prevented further developments, despite Zuelzer's strenuous efforts to involve the pharmaceutical industry. In America, in 1911-12, another medical student, Ernest Lyman Scott, produced an alcoholic extract that reduced glycosuria in four diabetic dogs [7] and, in 1919, Israel Kleiner reported on an aqueous extract that reduced glycaemia (which by then had become measurable in small volumes of blood) in dogs [8]. Interestingly, both Kleiner and Scott received only lukewarm encouragement from their seniors, the latter by none other than John James Rickard Macleod, at the time professor of physiology in Cleveland, Ohio. The most famous case (casualty?) was that of Nicolae Paulescu, also professor of physiology in Bucharest after a brilliant career in Paris, whose results on blood glucose reduction in dogs following injection of a pancreatic extract were published in June 1921 [9], just as work was beginning in Toronto.

Frederick Grant Banting and Charles Herbert Best started ligating ducts and extirpating pancreases in dogs on May 17, 1921. A series of intense, if not always consequential, experiments-brilliantly documented in Bliss's volume [1] —ended up a year later, May 3, 1922, with a report to the Association of American Physicians on the first ever rescue from coma of a young diabetic patient. The presentation was under the names of the team that had gathered over the months to make the miracle possible. They were, in alphabetical order: FG Banting, CH Best, JB Collip, W Campbell, AA Fletcher, JJR Macleod and EC Noble. Collip, assisted by Noble, was the skilled biochemist who had made the pancreatic extract viable for administration in humans. Campbell and Fletcher the physicians who treated the first patients in Toronto General Hospital. Macleod was the experienced researcher whose rational guidance made the achievement possible. Of interest, and doubtless benefit to clinical application, Banting's initial idea that it was necessary to let the exocrine pancreas atrophy in order to extract its "internal secretion", which entailed a long, cumbersome and expensive process to harvest uncertain amounts of active substance, proved superfluous. The team was soon able to produce plenty more potent extract from whole pancreases purchased from the local slaughterhouse.

The early months of 1922 , however, were intensely frustrating because of unexpected technical difficulties. Suddenly, the Toronto team was unable to (re)produce the extract and meet the demand of physicians across North America, whose ailing patients had become aware of the new developments. Initially, the Toronto team did not want to patent or profit from the discovery, but the pressure to develop production on an industrial scale led them to reach an agreement with Eli Lilly \& Co. of Indianapolis that would leave researchers outside the United States free to produce insulin without royalties due, for the benefit of their patients. Banting, Best and Collip ceded their rights for one dollar each, and Macleod refused altogether to be associated with commercial exploitation of insulin.

Sadly, the company broke in bitter disagreement because of personality clashes on matters of priority which, paradoxically, were made worse by the awarding of the Nobel Prize in 1923 to Banting and Macleod, who shared with Best and Collip, respectively. Zuelzer and Paulescu recurred to the Nobel awarding committee, to no avail. Indeed, in their first publication on "The Internal Secretion of the Pancreas", Banting and Best had totally ignored Zuelzer and grossly misquoted Paulescu's results by wrongly stating that his extract had not reduced blood glucose in diabetic dogs [10]. It must be said that, in his acceptance speech and afterwards, Macleod was always fair in pointing out how much had been done by other teams in other countries and making clear that James Collip had produced the high-quality extract [11]. The Romanian diabetologists tried to have Paulescu's results recognized, at least posthumously, by the Nobel Committee on the occasion of the 50th anniversary of the award.

This story contains seeds of the good, the bad and the evil that have further grown around research to nowadays. Can any lessons be learned, with hindsight?

The discovery of insulin was a case of the right result arrived at for the wrong reasons, by wrong means, by nonexpert, enthusiastic researchers. In other words, all ingredients for success were there! Banting, a practising surgeon mostly experienced in treating war wounds on the frontline but not on dog pancreata, and Best, a student working for his thesis, had no research experience whatsoever. Macleod, a methodical, highly regarded researcher on metabolism, gave them credit and some lab space to produce results, which Banting and Best did, to a point. The first weeks were literally a carnage of dogs, as Banting gained experience in pancreatectomies and duct ligation. Whenever some extract could be obtained, it was tested on the whim of the day, without a clear plan of work, often missing to record vital experimental details. It took Macloed's strategic direction and Collip's laboratory skills to produce an injectable product. To generate results, genius and recklessness need mixing with a sense of direction and more than a fair amount of good luck!

Then, one should not forget the unsung heroes of medical research. The discovery of insulin cost the sacrifice of huge numbers of animals. Apart from the dogs in Toronto 
and elsewhere, as many as 100,000 rabbits were sacrificed to titrate insulin "units" [1]. Anti-vivisection movements were active in Toronto in the 1920's and manifested strongly against "the unproven effects of such tribal superstitions as substituting animal organs for lost human ones, only to cause seizures to patients in their torture chambers". Sensitivities about animal welfare have changed a lot since then, not necessarily for better and perhaps reserving more empathy for house pets and primates than rodents. Today, it would be unthinkable to submit to an Ethics Committee the sort of experiments carried out by Claude Bernard, himself husband and father to fervent anti-vivisectionists. However, when it comes to rats, mice and other "lesser" forms of life, the feeling lingers that public attention is not always paid to avoid unnecessary suffering. Can it be stated with absolute certainty that animals are sacrificed only if and when unavoidable? Is adequate consideration always given to alternative approaches when planning experiments?

Another point for meditation descends from Louis Pasteur's "Le hazard ne favorise que les esprits preparée". Indeed, prepared minds are never in large supply. Had Schering first and, later on, Hoffman La Roche given more credit to Zuelzer and his collaboration with their own employee Camille Reuter (possibly to be considered as Zuelzer's Collip), insulin might have been manufactured in Europe before the Great War. Had Macleod listened more carefully to Scott, lives might have been saved in America ten years earlier. Minkowski himself did not give much credit to Zuelzer's results, and Paulescu was desperately isolated and short of facilities in post-war Romania. In fact, the whole European continent was no longer fertile ground for non-military research as the seeds for WW2 were sown among the ruins of WW1. Only Britain and Denmark were ready to start producing insulin on an industrial scale [12]. The state of Germany's debacle is well illustrated by the anecdote of a lecture given by Oskar Minkowski in Wroclaw in the spring of 1923. Thirty-four years after showing the link between pancreas and diabetes, the old professor had to write Banting and Best to ask for reprints-his University could not afford to subscribe to American journals - and apply, almost plead, for some insulin. Minkowski's lectures were always well attended and this time, too, the venerable professor did not disappoint his students. He declared how he had once dreamed of becoming the father of diabetes but then, after the brilliant work of younger researchers in the New World, had to content himself with being its grandfather. He then lifted a vial from his pocket and announced it to be the first insulin to reach Germany, a personal present from its Canadian discoverers. Two patients were brought in the lecture theatre, a child with ketoacidosis and an elderly man with a foot ulcer. Now, he asked, who should be given the life saving insulin? The child, suggested the students. But
Minkowski sadly objected that the child could not be kept alive much longer with the small supply available, which instead might help to heal the older man's ulcer [1]. This episode may remind us of similar painful choices in Intensive Care Units at the height of the COVID pandemic. In any event, once hyperinflation was over, insulin production started also in Germany in November 1923, months after Denmark, and Minkowski chaired the supervising insulin committee. Other producers, large and small, mushroomed in and out of Europe in the following years.

As Evil grew in devastated Europe, it led to the largest ever haemorrhage of active scientists and thinkers leaving the old for the new world. The field of diabetes was no exception. Paulescu, although a brilliant scientist, was at the head of a rabid anti-Semite movement in his country [13]. Zuelzer, at the receiving end of the same Evil, just managed to emigrate to America, where he finished his days as a practitioner regretting his lost chance to be the father of insulin [14].

Regrets! Those were the days when research aimed at accruing knowledge, penetrating the nature of things. Positivism was the word of the day and Doktor Faustus was its prophet. A scientist could barter his soul for a glimpse at the Essence of the Universe. Although, then as now, big discoveries led to great honours, only well connected, independently wealthy, exquisitely intelligent individuals could afford the selfless pursuit of knowledge. Even then, not necessarily for the greater benefit of mankind. Glory, not money, was the reward. An academic career has never been a money-maker, at least at inception, but in today's world of growing inequalities remains one of few paths left to upward mobility. Need and, sometimes, greed mix with the pursuit of results. Although perhaps overemphasized [15], concerns are growing about the pressures put on young researchers and the potential distortions in reporting their results. To publish seems to matter more than to discover, patenting more than construing, start upping more than manufacturing. Anybody who's done bench work with raw reagents knows how much method, precision, patience, intuition, green thumb and good luck it takes to produce consistent results. Also the Toronto team experienced a frustrating inability to reproduce their own results just when they most needed to. But today most findings, even those published in top journals, cannot be repeated in other laboratories [16]. Retractions are the order of the day. Lesser me-too papers parrot well known data, killing animals in the process for badly designed experiments $[17,18]$. Concurrently publishers, straight and predatory, multiplicate. Bibliometric indexes, also in active proliferation, appear to stimulate quantity though not necessarily preserve quality of the science they were meant to measure and improve. While scientists of yesteryear abhorred profiting from their discoveries, e.g. the sphygmomanometer, insulin or other true advancements, 
today's universities incentivize their staff to patent new products almost before their validity is confirmed.

This is not harking back to the good old days. We face serious challenges today, as dissatisfaction and mistrust in Science grow in the general public. Just as progress has brought the greatest benefits ever to mankind, all sorts of anti-scientific feelings are developing in Society. Larger and larger groups manifest against vaccinations, genetic engineering, exploitation of energy, the free movement of ideas, people and goods. Rather than spread positive ideas and rational attitudes, modern means of global communication nurture the ghosts of superstition, intolerance and dogmatism that one hoped had been buried for good after the tragedies of the past century. Against the return of the witch hunters, Science should not fail to live up to its highest standards, its best traditions. If must not lend ground to even the slightest criticism!

It is worth going back, at least in spirit, to the early pioneering years that saw life being literally injected back into human beings, mostly children, who awaited death reduced to skin and bones. Suddenly, they could put on flesh and start to grow again. Elliott P Joslin, a man of deep religious commitment, talked of how what he saw in those years reminded him of Ezechiel's vision of the valley of dry bones (Ezekiel XXXVII, 1-14):

"... and behold, there were many in the open valley; and, lo, they were dry.

And He said onto me, Son of Man, can these bones live?

And ... lo, the sinews and the flesh came upon them and the skin covered them above: but there was no breath in them.

Then said He unto me, "Profesy unto the wind, prophecy, Son of Man, and say to the wind. Thus said the Lord God: 'Come from the four winds, $O$ breath, and breath upon these slain, that they may live.",

So I prophesied as He commanded me, and the breath came into them, and they lived, and stood up upon their feet, an exceeding great army. (...)"

\section{Funding None}

\section{Compliance with ethical standards}

Conflicts of interest The author declares that he has no conflict of interest

Ethical approval This manuscript does not include human or animal studies for which ethics approval is required.
Informed consent No human procedure for which an informed consent is required was performed for the writing of this paper.

\section{References}

1. Bliss M (1982) The Discovery of Insulin The University of Chicago Press Chicago

2. Barron M (1920) The relation of the islet of Langerhans to diabetes with special reference to cases of pancreatic lithiasis Surg Gynecol Obstet 31437448

3. Banting FG (1940) The story of insulin. Unpublished manuscript. Banting papers. University of Toronto. (quoted in Bliss M, 1982)

4. von Mering J, Minkowski O (1889) Diabetes mellitus nach Pankreasextirpation Zbl Klin Med 103934

5. Langerhans $P$ (1869) Beiträge zur mikroscopischen Anatomie der Bauchspeicheldrüse. Wilhelms- Friedrich Wilhelm Universität zu Berlin, printed by G. Lange

6. Zülzer G (1908) Ueber Versuche einer spezifischen Ferment Therapie des Diabetes Zeitschrift $\mathrm{f} \exp$ Pathologic u Therapie 5 307318

7. Scott EL (1912) On the influence of intravenous injections of an extract of the pancreas on experimental pancreatic diabetes Am J Phys 9306310

8. Kleiner IS (1919) The action of intravenous injections of pancreas emulsions in experimental diabetes J Biol Chem 40153170

9. Paulescu NC (1921) Action de l'extrait pancréatique injecté dans le sang, chez un animal diabètique C R Soc Biol Paris 85555

10. Banting FG, Best CH (1922) The internal secretion of the pancreas J Lab Clin Med 7256271

11. Waller $\mathbf{J}$ (2002) Fabulous science: fact and fiction in the history of scientific discovery Oxford University Press Oxford

12. Porta M, Jörgens V (2020) Three and a half thousand years of diabetes research V Jörgens M Porta Eds Unveiling Diabetes-Historical Milestones in Diabetology Front Diabetes Karger Diabetes 298303

13. De Leiva-Pérez A, Bruguèz-Bruguèz E, De Leiva A (2010) From a pancreatic extracts to artificial pancreas: history, science and controversies about the discovery of the pancreatic antidiabetic hormone: VI: NICOLAE C Paulescu: light and darkness Av Diabetol 26463471

14. Jörgens V (2020) They got very near the goal: Zülzer, Scott, and Paulescu V Jörgens M Porta Eds Unveiling Diabetes Historical Milestones in Diabetology Front Diabetes karger 5872

15. Fanelli D (2018) Is science really facing a reproducibility crisis, and do we need it to? PNAS $11526282631 \mathrm{https}$ ://doi. org/10.1073/pnas.178272114

16. Baker M (2016) Is there a reproducibility crisis? Nature 533452 454

17. Reardon S (2016) A mouse's house may ruin studies Nature 530 264

18. Macleod M (2011) Why animal research needs to improve Nature 477511

Publisher's Note Springer Nature remains neutral with regard to jurisdictional claims in published maps and institutional affiliations. 